\title{
An Applied Integrated Management Course on Business Disruption in the Digital Age
}

\author{
Barbara D. Klein \\ University of Michigan-Dearborn
}

This paper describes an Applied Integrated Management course developed as part of an MBA degree program offered at a regional, public university. The course is focused on business disruption in the digital age and seeks to develop integrative thinking in MBA students. Material from the academic disciplines of economics, statistics, information systems, and organizational behavior provide the foundation for an indepth exploration of course topics including human decision making and machine learning; robotics, digitization, and innovation; productivity, economic effects, and technological innovation; platforms and network effects; platform architecture and disruption; monetization and openness of platforms; the crowd, expertise, and prediction markets; the sharing economy, blockchain and economic impacts; and regulation, work, and labor in the sharing economy. The MBA program, course design, course materials, and assignments are described. Faculty at institutions interested in combating a 'silo' approach in the design and delivery of MBA programs and university instruction generally may wish to adopt the approach described in the paper.

Keywords: business disruption, integrative thinking, MBA program, course design

\section{INTRODUCTION}

A course on business disruption in the digital age was developed for a Masters of Business (MBA) degree program at a regional public university. The MBA program requires that students complete four courses in a category labeled Applied Integrated Management. The goal of the Applied Integrated Management Courses in the MBA program is to encourage students to integrate the content of their MBA core courses as they apply coursework in an integrated fashion to business problems and scenarios. While MBA programs have sometimes been criticized as encouraging students to think about business problems in a 'silo' fashion, the Applied Integrated Management courses explicitly encourage an interdisciplinary mindset among the MBA students in the program.

The course described in this paper was developed as an online course in the MBA program. Titled "Business Disruption in the Digital Age: Machine Learning, Platforms, and the Crowd," the course integrates material from economics, statistics, information systems, and organizational behavior and applies this material in a series of integrative assignments. The remainder of the paper discusses the MBA program for which the course was developed, the course on business disruption in the digital age, and assignments developed for the course. 


\section{THE STRUCTURE OF THE MBA PROGRAM}

The MBA program for which the course was developed requires students to complete nine core courses, four Applied Integrated Management Courses, and three elective course which can be used to complete a concentration in a business discipline. The cores course include: (1) Developing and Interpreting Financial Information, (2) Economic Analysis: Firm and Consumer, (3) Corporate Social Responsibility, (4) Applied Statistical Modeling, (5) Financial Fundamentals and Value Creation, (6) Computer and Information Systems, (7) Marketing Management, (8) Organization Behavior, and (9) Operations Management.

The goal of the Applied Integrated Management Courses is to develop the knowledge and skills needed to integrate knowledge across disciplinary areas in order to solve business problems. Applied Integrated Management Courses are required to have at least three courses as prerequisites so students generally enroll in the Applied Integrated Management courses near the end of the MBA program. The Applied Integrated Management Courses are designed to meet the goal of encouraging students to develop the ability to view and address business problems in a more integrative way than the traditional "silo" fashion in which each course in an MBA program addresses material drawn from one business area (Bandyopadhyay et al., 2011; Blass and Weight, 2005; Hazen and Higby, 2005; Moldoveanu and Martin, 2008; Shield and Coughlan, 2007)

\section{THE BUSINESS DISRUPTION COURSE}

A course titled "Business Disruption in the Digital Age: Machine Learning, Platforms, and the Crowd" was developed as an Applied Integrated Management Course. The course addresses the implications of digitization on business operations by integrating material from the core business disciplines of economics, statistics, information systems, and organizational behavior. The course description is presented in Table 1.

\section{TABLE 1 COURSE DESCRIPTION}

This course integrates research from the fields of economics, mathematics and statistics, information systems, and organizational behavior as they inform our understanding of the three interrelated phenomena of machine learning, the platform, and the crowd that are disrupting and transforming businesses organizations, industries, and the economy. Our study of machine learning will contrast human decision making (and it limitations and biases) with machine learning and examine the organizational and economic effects of robotics, digitization, and other technological innovations. Our study of platforms will focus on network effects, technical architecture, and strategies related to the monetization and openness of platforms. Our study of the crowd will focus on crowd-based expertise, prediction markets, economic impacts of the sharing economy, blockchain, regulatory issues in the sharing economy, and issues of the nature of work and labor in the sharing economy. We will apply and integrate research in these areas to the development of insights into business problems with an emphasis on shifts in traditional business organizations and emerging types of organizations that use technological innovations in ways that have the potential for disrupting and transforming industries. Students interested in careers in a wide variety of business professions will find the knowledge and skills gained through this course to be useful in their professional endeavors.

The course is focused on the eight goals presented in Table 2. 


\section{TABLE 2}

\section{COURSE GOALS}

1. Explain the following aspects of machine learning and artificial intelligence: human decision making versus machine learning, robotics, digitization, productivity effects of machine learning and artificial intelligence, and technological innovation.

2. Apply the following aspects of machine learning and artificial intelligence: human decision making versus machine learning, robotics, digitization, productivity effects of machine learning and artificial intelligence, and technological innovation.

3. Explain the following aspects of platforms: network effects, platform architecture, platform disruption, monetization, and openness.

4. Apply the following aspects of platforms: network effects, platform architecture, platform disruption, monetization, and openness.

5. Explain the following aspects of the crowd: crowd-based expertise, prediction markets, the sharing economy, blockchain, economic impacts of the sharing economy, regulation of the sharing economy, and work and labor in the sharing economy.

6. Apply the following aspects of the crowd: crowd-based expertise, prediction markets, the sharing economy, blockchain, economic impacts of the sharing economy, regulation of the sharing economy, and work and labor in the sharing economy.

7. Integrate the principles of machine learning and artificial intelligence, platforms, and the crowd in the solution of business problems and in the development of business initiatives.

8. Communicate an application of the principles of machine learning and artificial intelligence, platforms, and the crowd orally and in writing.

Readings from the four books shown in Table 3 are assigned in the course.

TABLE 3

\section{COURSE TEXTS}

Brynjolfsson, E., \& McAfee, A. (2016). The Second Machine Age: Work, Progress, and Prosperity in a Time of Brilliant Technologies. New York: W. W. Norton \& Company, Inc.

McAfee, A., \& Brynjolfsson, E. (2017). Machine Platform Crowd: Harnessing Our Digital Future. New York: W. W. Norton \& Company, Inc.

Parker, G. G., Van Alstyne, M. W., \& Choyudary, S. P. (2016). Platform Revolution. New York: W. W. Norton \& Company, Inc.

Sundararajan, A. (2016). The Sharing Economy. Cambridge: The MIT Press.

Course topics include human decision making and machine learning; robotics, digitization, and innovation; productivity, economic effects, and technological innovation; platforms and network effects; platform architecture and disruption; monetization and openness of platforms; the crowd, expertise, and prediction markets; the sharing economy, blockchain and economic impacts; and regulation, work, and labor in the sharing economy. Table 4 presents readings organized by these topics which interested readers may wish to consult as they develop courses covering these topics. 


\section{TABLE 4 \\ READINGS BY TOPIC}

\section{Introduction to Business Disruption in the Digital Age}

Silver, D. et al. (2016). Mastering the game of Go with deep neural nets and search trees. Nature, 529(28), 484-498.

Stein, J. (2015). Tales from the sharing economy. Time. February 7. https://time.com/3687305/testingthe-sharing-economy/.

\section{Human Decision Making and Machine Learning}

Canhoto, A. I., \& Clear, F. (2020). Artificial intelligence and machine learning as business tools: A framework for diagnosing value destruction potential. Business Horizons. 63(2), 183-193.

Grove, W. M. et al. (2000). Clinical versus mechanical prediction: A meta-analysis. Psychological Assessment, 12(1), 19-30.

\section{Robotics, Digitization, and Innovation}

Koh, B., Hann, I., \& Raghunathan, S. (2019). Digitization of music: Consumer adoption amidst piracy, unbundling, and rebundling. MIS Quarterly, 43(1), 23-45.

Beane, M. (2019). Learning to work with intelligent machines. Harvard Business Review, 97(5), 140148.

\section{Productivity and Economics Effects and Technological Innovation}

Agrawal, A., Gans, J., \& Goldfarb, A. (2018). The (surprisingly) simple economics of artificial intelligence. Rotman Management Magazine, Spring 2018, 7-11.

Autor, D. H. (2015). Why are there still so many jobs? The history and future of workplace automation. Journal of Economic Perspectives, 29(3), 3-30.

\section{Platforms and Network Effects}

Eisenmann, T., Parker, G., Van Alstyne, M. (2006). Strategies for two-sided markets. Harvard Business Review, 84(10), 92-101.

Evans, D. S., \& Schmalensee, R. (2017). Network effects: March to the evidence, not to the slogans. Antitrust Chronicle, 1, 1-10.

\section{Platform Architecture and Disruption}

Ceccagnoli, M., Forman, C., Huang, P., \& Wu, D. (2012). Cocreation of value in a platform ecosystem: The case of enterprise software. MIS Quarterly, 36(1), 263-290.

Iansiti, M., \& Lakhani, K. R. (2014). Digital ubiquity: How connections, sensors, and data are revolutionizing business. Harvard Business Review, 92(11), 3-11.

\section{Monetization and Openness of Platforms}

Eisenmann, T. R. (2008). Managing proprietary and shared platforms. California Management Review, 50(4), 31-53.

Zhu, Feng, \& Iansiti, M. (2019). Why some platforms thrive and others don't. Harvard Business Review, 97(1), 118-125.

\section{The Crowd, Expertise, and Prediction Markets}

Boudreau, K., \& Lakhani, K. R. (2013). Using the crowd as an innovation partner. Harvard Business Review, 91(4), 60-69.

Arrow, K. J. et al. (2008). The promise of prediction markets. Science, 320, 877-878. 


\section{The Sharing Economy, Blockchain, and Economic Impacts}

Gaur, V., \& Gaiha, Abhinav. (2020). Building a transparent supply chain: Blockchain can enhance trust, efficiency, and speed. Harvard Business Review, 98(3), 94-103.

Ordanini, A., Lucia, M., \& Pizzetti, M. (2011). Crowd-funding: Transforming customers into investors through innovative service platforms. Journal of Service Management, 22(4), 443-470.

\section{Regulation, Work, and Labor in the Sharing Economy}

Fisman, R., \& Luca, M. (2016). Fixing discrimination in online marketplaces. Harvard Business Review, 94(12), 88-95.

Malhotra, A., \& Van Altyne, M. (2014). The dark side of the sharing economy....and how to lighten it. Communications of the ACM, 57(11), 24-27.

The course is organized into six units, three of which have multiple modules. After an introductory unit, the majority of the content is organized into three units with four modules each. The course wraps up with two modules focused first on an individual project and then on reflection and peer evaluation. The units and modules are presented in Table 5 along with the deliverables for each module.

TABLE 5

COURSE UNITS AND MODULES

\begin{tabular}{|c|c|c|c|}
\hline Unit & Module & Topic & Deliverables \\
\hline 1 & 1 & $\begin{array}{l}\text { Introduction to Business Disruption in the } \\
\text { Digital Age }\end{array}$ & $\begin{array}{l}\text { - Quiz } \\
\text {-3 Online Discussions }\end{array}$ \\
\hline 2 & 1 & $\begin{array}{l}\text { Human Decision Making and Machine } \\
\text { Learning }\end{array}$ & $\begin{array}{l}\text { - Quiz } \\
\text {-3 Online Discussions }\end{array}$ \\
\hline 2 & 2 & Robotics, Digitization, and Innovation & $\begin{array}{l}\text { - Quiz } \\
\text {-3 Online Discussions }\end{array}$ \\
\hline 2 & 3 & $\begin{array}{l}\text { Productivity and Economic Effects and } \\
\text { Technological Innovation }\end{array}$ & $\begin{array}{l}\cdot \text { Quiz } \\
\text {-3 Online Discussions }\end{array}$ \\
\hline 2 & 4 & $\begin{array}{l}\text { Machine Learning: Concluding } \\
\text { Application and Integration }\end{array}$ & $\begin{array}{l}\text { - Analysis and Application Team } \\
\text { Exercise for Unit } 2\end{array}$ \\
\hline 3 & 1 & Introduction to Platforms & $\begin{array}{l}\text { - Quiz } \\
\text {-3 Online Discussions }\end{array}$ \\
\hline 3 & 2 & $\begin{array}{l}\text { Network Effects, Platform Architecture, } \\
\text { and Platform Disruption }\end{array}$ & $\begin{array}{l}\text { - Quiz } \\
\text { • } 3 \text { Online Discussions }\end{array}$ \\
\hline 3 & 3 & Monetization and Openness of Platforms & $\begin{array}{l}\text { - Quiz } \\
\text {-3 Online Discussions }\end{array}$ \\
\hline 3 & 4 & $\begin{array}{l}\text { Platforms: Concluding Application and } \\
\text { Integration }\end{array}$ & $\begin{array}{l}\text { - Analysis and Application Team } \\
\text { Exercise for Unit } 2\end{array}$ \\
\hline 4 & 1 & $\begin{array}{l}\text { The Crowd, Expertise, and Prediction } \\
\text { Market }\end{array}$ & $\begin{array}{l}\text { - Quiz } \\
\text {-3 Online Discussions }\end{array}$ \\
\hline 4 & 2 & $\begin{array}{l}\text { The Sharing Economy, Blockchain, and } \\
\text { Economic Impacts }\end{array}$ & $\begin{array}{l}\text { - Quiz } \\
\text {-3 Online Discussions }\end{array}$ \\
\hline 4 & 3 & $\begin{array}{l}\text { Regulation, Work, and Labor in the } \\
\text { Sharing Economy }\end{array}$ & $\begin{array}{l}\cdot \text { Quiz } \\
\text {-3 Online Discussions }\end{array}$ \\
\hline 4 & 4 & $\begin{array}{l}\text { The Crowd: Concluding Application and } \\
\text { Integration }\end{array}$ & $\begin{array}{l}\text { - Analysis and Application Team } \\
\text { Exercise for Unit } 2\end{array}$ \\
\hline 5 & 1 & Individual Project & • Individual Project \\
\hline 6 & 1 & $\begin{array}{l}\text { Final Exercise: Peer Evaluation and Self- } \\
\text { Reflection }\end{array}$ & $\begin{array}{l}\text { - Final Exercise: Peer Evaluation and } \\
\text { Self-Reflection }\end{array}$ \\
\hline
\end{tabular}




\section{ANALYSIS AND APPLICATION TEAM EXERCISES}

The Analysis and Application Team Exercises are designed as concluding exercises for each of the three multi-module units in the course. Students work in teams to develop their integrative thinking skills through collaboration in analysis and application of the unit's material and concepts to an industry selected by the team. Teams are required to select a different industry for each of the three Analysis and Application Team Exercises completed during the course. Table 6 describes the objective and requirements of the Analysis and Application Team Exercises for the Unit 2 Analysis and Application Team Exercise focused on machine learning.

TABLE 6

\section{ANALYSIS AND APPLICATION TEAM EXERCISE OBJECTIVE AND REQUIREMENTS} FOR MACHINE LEARNING UNIT

\section{Project Objective}

This Analysis and Application Team Exercise gives you an opportunity to work with a group of classmates to analyze and apply the conceptual concepts covered in this unit to an industry of your choice.

\section{Exercise Requirements}

1. Select an industry to which your team will apply the conceptual concepts covered in the three modules of this unit. You may select either an industry from the following list which is taken from page 13 of Platform Revolution

\begin{tabular}{|l|l|l|l|}
\hline Agriculture & $\begin{array}{l}\text { Communications and } \\
\text { Networking }\end{array}$ & Consumer Goods & Education \\
\hline $\begin{array}{l}\text { Energy and Heavy } \\
\text { Industry }\end{array}$ & Finance & Health Care & Gaming \\
\hline $\begin{array}{l}\text { Labor and } \\
\text { Professional Services }\end{array}$ & Local Services & $\begin{array}{l}\text { Logistics and } \\
\text { Delivery }\end{array}$ & Media \\
\hline Operating Systems & Retail & Transportation & Travel \\
\hline
\end{tabular}

or you may also select an industry from the "Industries at a Glance" list published by the U.S. Bureau of Labor Statistics. Your team will complete three analysis and application team exercises during the course. Your team will need to select a different industry for each of the three exercises.

2. Find resources related to the industry your team has selected for this assignment. You may use videos, movies, newspaper articles, magazine articles, books, and websites as appropriate for the industry you have selected. Your goal is to learn enough about the industry that you can provide an insightful analysis in the context of the conceptual concepts covered in the unit. Share the resources you find with the members of your team and discuss the material with the members of your team once everyone has read and/or watched the material. Keep a list of all the material used by your team for use in creating the reference list for the project.

3. Work with the members of your team to complete the deliverables listed and described below. 
Deliverables

A. Question and Answer Document. Create a document with your team's answers to the questions listed below. Your answers should reflect your team's best thoughts and analysis on these questions and reflect the input of all members of your team for each question.

1. How is the "machine" as covered in this unit used or applied in the industry you selected for this assignment.

2. Select a number (2-4) of key organizations in the industry you selected for this assignment. Describe and explain how they are using the "machine" as covered in this unit.

3. What organizations in the industry you have selected have been slow to adopt and apply the "machine" as covered in this unit? Why? If there are new entrants to the industry describe how they are using the "machine" as covered in this unit.

4. What effects has the "machine" as covered in this unit had on the industry you have selected.

5. What specific effects have the "machine" as covered in this unit had on labor in the industry? What specific effects has the "machine" as covered in this unit had on shareholders and other stakeholders in the industry you have selected?

6. How has the "machine" as covered in this unit affected barriers to entry in the industry you have selected?

7. How is the "machine" as covered in this unit likely to affect the industry in the short (13 years) and long-term future?

8. How does the "machine" as covered in this unit likely to affect the critical success factors for organizations in the industry?

9. What are the five most important pieces of advice related to the "machine" as covered in this unit that you would offer organizations in the industry you have selected?

10. How does the "machine" as covered in this unit affect professionals working in the industry you have selected?

11. What are the five most important pieces of advice related to the "machine" as covered in this unit that you would offer professionals working in the industry you have selected.

12. What are the five most important pieces of advice related to the "machine" as covered in this unit that you would offer undergraduate college students hoping to work in the industry in the future?

13. Identify two regulatory and legal challenges and potential solutions to these challenges related to the "machine" as covered in this unit in the industry you have selected.

14. Identify two labor or human resource challenges and potential solutions to these challenges related to the "machine" as covered in this unit in the industry you have selected.

15. Identify three other (not covered in questions 13 and 14) significant challenges currently facing organizations in the industry you have selected and explain how the "machine" as covered in this unit may be applied to meet these challenges.

B. Industry Paper. Your team will write an industry paper to inform readers in the industry or potential entrants to the industry about the current state and future of the "machine" in the industry you have selected. The industry paper should present a synthesis of your analysis and application and be presented in an in-depth fashion so that actual and potential organizations and employees in the industry can position themselves for the future with respect to the "machine." The industry paper should be informed by the course readings and other materials in this unit as well as by the industry-related resources your team read, watched, and discussed as part of this assignment. You should use your Question and Answer Document along with further discussion by your team as you craft and write your Industry Paper. 


Your industry paper should be 6-8 pages of single-spaced text (Times New Roman, 11 point
font), written in narrative form, and organized to follow the outline below. Insert the name
of the industry your team has selected in place of the "Y" variable in the outline below.
I. Introduction
II. Current State of the Machine in the Y Industry
III. Effects of the Machine in the Y Industry
a. Current
b. Future
IV. Recommendations and Advice Related to the Machine in Y Industry
a. Advice to Organizations Currently in the Industry
b. Advice to Potential Organizational Entrants to the Industry
c. Advice to People Currently Working in the Industry
d. Advice to People Interested in Working in the Industry in the Future
V. Regulatory and Legal Challenges Related to the Machine in the Y Industry
VI. Additional Key Insights Related to the Machine in the Y Industry
VII. Conclusion

\section{INDIVIDUAL PROJECT}

In addition to the three Analysis and Application Team Exercises students work individually on a project throughout the course. The individual project is focused on the development of integrative thinking skills and requires students to apply and analyze course concepts to an organization of their choice. Table 7 describes the objective and requirements of the individual project.

TABLE 7

\section{INDIVIDUAL PROJECT OBJECTIVE AND REQUIREMENTS}

\section{Project Objective}

This individual project gives you an opportunity to work independently to analyze and apply the conceptual concepts covered in the course to an organization in which you work or hope to work in the future.

\section{Exercise Requirements}

1. Select an organization in which you work or an organization in which you hope to work in the future to which you will apply the conceptual concepts covered in all of the course modules.

2. Find resources related to the organization you have selected for this assignment. You may use videos, movies, newspaper articles, magazine articles, books, and websites as appropriate. You may also draw on your personal experience and/or interviews with other people who work in the organization, but you should not rely exclusively on personal experience and interviews for background material for the assignment. Keep a list of all the material you use for use in creating the reference list for your project.

\section{Deliverable}

Organizational Analysis and Application Paper. Imagine that the CEO or owner of the organization you selected for this assignment has asked you to write a paper informing them about the current state and future of the "machine," "platform," and "crowd" in the organization you have selected. Your paper should present a synthesis of your analysis and application and be presented in an in-depth fashion so that the CEO or owner can position themselves for the future with respect to the "machine," "platform," and "crowd." The paper should be informed by the course readings and other course materials as well as by the resources you read as part of this assignment 


\section{CONCLUSION}

The course on digital disruption in the digital age provides a model that can be adopted by faculty interested in building courses that help students develop integrative thinking skills in MBA programs or other degree programs. The course materials and assignments discussed in the paper are designed to build these skills and encourage students to bring an interdisciplinary approach to their problem solving both

during their course experience and throughout their careers. This approach can be adopted by faculty at other institutions interested in combating a 'silo' approach in the design and delivery of MBA programs and university instruction generally.

\section{REFERENCES}

Agrawal, A., Gans, J., \& Goldfarb, A. (2018, Spring). The (surprisingly) simple economics of artificial intelligence. Rotman Management Magazine, pp. 7-11.

Arrow, K.J., Forsythe, R., Gorham, M., Hahn, R., Hanson, R., Ledyard, J.O., . . . Zitzewitz, E. (2008). The promise of prediction markets. Science, 320, 877-878.

Autor, D.H. (2015). Why are there still so many jobs? The history and future of workplace automation. Journal of Economic Perspectives, 29(3), 3-30.

Bandyopadhyay, J., Coleman, L.J., \& DeWolfe, S. (2011). Interdisciplinary education for global strategy. Competition Forum, 9(2), 378-388.

Beane, M. (2019). Learning to work with intelligent machines. Harvard Business Review, 97(5), 140148.

Blass, E., \& Weight, P. (2005). The MBA is dead - part 1: God save the MBA! On the Horizon, 13(4), 229-240.

Boudreau, K., \& Lakhani, K.R. (2013). Using the crowd as an innovation partner. Harvard Business Review, 91(4), 60-69.

Canhoto, A.I., \& Clear, F. (2020). Artificial intelligence and machine learning as business tools: A framework for diagnosing value destruction potential. Business Horizons, 63(2), 183-193.

Ceccagnoli, M., Forman, C., Huang, P., \& Wu, D. (2012). Cocreation of value in a platform ecosystem: The case of enterprise software. MIS Quarterly, 36(1), 263-290.

Eisenmann, T., Parker, G., Van Alstyne, M. (2006). Strategies for two-sided markets. Harvard Business Review, 84(10), 92-101.

Eisenmann, T.R. (2008). Managing proprietary and shared platforms. California Management Review, 50(4), 31-53.

Evans, D.S., \& Schmalensee, R. (2017). Network effects: March to the evidence, not to the slogans. Antitrust Chronicle, 1, 1-10.

Fisman, R., \& Luca, M. (2016). Fixing discrimination in online marketplaces. Harvard Business Review, 94(12), 88-95.

Gaur, V., \& Gaiha, A. (2020). Building a transparent supply chain: Blockchain can enhance trust, efficiency, and speed. Harvard Business Review, 98(3), 94-103.

Grove, W.M., Zald, D.H., Lebow, B.S., Snitz, B.E., \& Nelson, C. (2000). Clinical versus mechanical prediction: A meta-analysis. Psychological Assessment, 12(1), 19-30.

Hazen, M.A., \& Higby, M.A. (2005). Teaching an issues-based interdisciplinary course: Diversity in management and marketing. Journal of Management Education, 29(3), 403-426.

Iansiti, M., \& Lakhani, K.R. (2014). Digital ubiquity: How connections, sensors, and data are revolutionizing business. Harvard Business Review, 92(11), 3-11.

Koh, B., Hann, I., \& Raghunathan, S. (2019). Digitization of music: Consumer adoption amidst piracy, unbundling, and rebundling. MIS Quarterly, 43(1), 23-45.

Malhotra, A., \& Van Altyne, M. (2014). The dark side of the sharing economy... and how to lighten it. Communications of the ACM, 57(11), 24-27. 
Moldoveanu, M.C., \& Martin, R.L. (2008). The future of the MBA: Designing the thinker of the future. Oxford: Oxford University Press.

Ordanini, A., Lucia, M., \& Pizzetti, M. (2011). Crowd-funding: Transforming customers into investors through innovative service platforms. Journal of Service Management, 22(4), 443-470.

Shield, S., \& Coughlan, R. (2007). Designing the MBA of tomorrow. Design Management Review, 18(3), $55-62$.

Silver, D., Huang, A., Maddison, C.J., Guez, A.,Sifre, L., van den Driessche, G., . . Hassabis, D. (2016). Mastering the game of Go with deep neural nets and search trees. Nature, 529(28), 484-498.

Stein, J. (2015, February 7). Tales from the sharing economy. Time. Retrieved from https://time.com/3687305/testing-the-sharing-economy/

Zhu, F., \& Iansiti, M. (2019). Why some platforms thrive and others don't. Harvard Business Review, 97(1), 118-125. 